\title{
By-catch species susceptibilities and potential for survival in Algarve (southern Portugal) deep-water crustacean trawl fishery
}

\author{
Ana C. Adão ${ }^{1}$, Michael Breen ${ }^{2}$, Moritz Eichert ${ }^{1}$, Teresa C. Borges ${ }^{1}$ \\ ${ }^{1}$ Centre of Marine Sciences, University of Algarve, Gambelas Campus, 8005-139 Faro, Portugal. \\ (ACA) (Corresponding author) E-mail: catarinavadao@ gmail.com. ORCID-iD: https://orcid.org/0000-0002-7662-2143 \\ (ME) E-mail: moritz.eichert@ gmail.com. ORCID-iD: https://orcid.org/0000-0003-3565-1762 \\ (TCB) E-mail: tborges@ ualg.pt. ORCID-iD: https://orcid.org/0000-0002-6414-0083 \\ ${ }^{2}$ Institute of Marine Research, 5817 Bergen, Norway. \\ (MB) E-mail: michael.breen@imr.no. ORCID-iD: https://orcid.org/0000-0002-1082-1043
}

\begin{abstract}
Summary: Bottom trawling for crustaceans in Portuguese coastal waters is an important fishery in terms of revenue, despite its negative impacts on deep-sea ecosystems. This fishery catches large amounts of unwanted species that were discarded for various reasons before the introduction of the Landing Obligation, which banned the discarding of regulated species. However, where it can be demonstrated that a species has an acceptably high likelihood of survival, exemptions to this ban may be granted. In this study, time-to-mortality was used to estimate immediate mortality rates and identify important biological characteristics determining the susceptibility of 14 by-catch species, most with commercial interest (Conger conger, Galeus melastomus, Helicolenus dactylopterus, Lepidorhombus boscii, Lophius budegassa, Lophius piscatorius, Merluccius merluccius, Micromesistius poutassou, Mullus surmuletus, Phycis blennoides, Scyliorhinus canicula, Trigla lyra, Trachurus trachurus and Trachurus picturatus). Species with potential to survive after the discarding process were identified and a short-term survival assessment of conger eel (Conger conger) was performed. The results suggest that species with scales, gas bladder and high metabolic rates have higher post-discard mortality. Size was a critical factor determining survival in some species, with smaller individuals dying faster. The short-term survival rate of conger eel was determined to be $84 \%$ (95\% CI: 75.5 to $93.3 \%$ ). The methodology and results from this study can help identify species that may survive the discarding process and factors influencing their survival.
\end{abstract}

Keywords: by-catch; discards; time-to-mortality; biological traits; survival; trawling; southern Portugal.

Vulnerabilidad de las especies accesorias y su potencial de supervivencia en la pesquería de arrastre de fondo de crustáceos en el Algarve (sur de Portugal)

Resumen: El arrastre de fondo en las aguas costeras portuguesas es una pesquería de gran importancia económica, a pesar de sus efectos negativos sobre los ecosistemas marinos. Esta pesquería captura grandes cantidades de especies no deseadas que antes de la norma de desembarque eran descartadas por diversas razones. Después de la entrada en vigor de dicha norma, el descarte de especies reguladas está prohibido. Sin embargo, existen excepciones si se demuestra que una especie tiene grandes probabilidades de supervivencia después de su descarte. En este estudio, se utilizó un índice tiempo-para-mortalidad para estimar las tasas de mortalidad inmediata e identificar las características biológicas importantes que determinan la vulnerabilidad de 14 especies descartadas, la mayoría con interés comercial (Conger conger, Galeus melastomus, Helicolenus dactylopterus, Lepidorhombus boscii, Lophius budegassa, Lophius piscatorius, Merluccius merluccius, Micromesistius poutassou, Mullus surmuletus, Phycis blennoides, Scyliorhinus canicula, Trigla lyra, Trachurus trachurus y Trachurus picturatus). Además, se realizó un estudio de supervivencia a corto plazo para el congrio (Conger conger). Mediante el índice se determinó las especies con mayor probabilidad de sobrevivir. Los resultados sugieren que las especies con escamas, vejiga natatoria y elevada tasa metabólica tienen una mayor mortalidad post-descarte. El tamaño del animal fue un factor determinante para algunas de las especies estudiadas, observándose una mayor mortalidad en los individuos de menor tamaño. La supervivencia a corto plazo del congrio fue del $84 \%$ (95\% intervalo de confianza: 75.5 a $93.3 \%$ ). La metodología y los resultados de este estudio pueden ayudar a identificar las especies con mayor probabilidad de supervivencia al proceso de descarte y factores que influyen en su supervivencia.

Palabras clave: capturas accesorias; descartes; tiempo-para-mortalidad; características biológicas; supervivencia; arrastre; sur de Portugal.

Citation/Cómo citar este artículo: Adão A.C., Breen M., Eichert M., Borges T.C. 2018. By-catch species susceptibilities and potential for survival in Algarve (southern Portugal) deep-water crustacean trawl fishery. Sci. Mar. 82S1: 141-149. https://doi.org/10.3989/scimar.04740.02A

Editor: M. Demestre. 
Received: December 1, 2017. Accepted: August 13, 2018. Published: October 11, 2018.

Copyright: (C) 2018 CSIC. This is an open-access article distributed under the terms of the Creative Commons Attribution 4.0 International (CC BY 4.0) License.

\section{INTRODUCTION}

Despite its impact on marine ecosystems through the modification of sea-bottom morphology and resuspension of sediments, bottom trawling is one of the most common fishing practices around the world (Pusceddu et al. 2014, Clark et al. 2015). Demersal trawl nets collect an extensive range of species and sizes and thus have high discard rates. By-catch is defined as any organism caught unintentionally. Unwanted catch is the proportion of the catch that has no value to the fisher and is frequently discarded, which may include undersized or damaged commercially important species (i.e. target species); commercially important species for which the fisher has no quota; and species with no commercial value. "The discard problem" raises several issues, including policy and ethical implications, fisheries management, and ecological, economic and technical concerns (Kelleher 2005). One of the key changes during the recent reform of the Common Fisheries Policy was the intention to "gradually eliminate the wasteful practice of discarding" (EU 2013). As a result, a discard ban (the "Landing Obligation") now obliges fishermen to keep and land all regulated species caught: i.e., species with quotas (total allowable catches) or minimum conservation reference sizes in the Mediterranean. However, if scientific evidence demonstrates that a species has an acceptably high survival when released from a particular fishery, then discarding of that species may be permitted (EU 2013).

Research estimating discard survival has been conducted in commercial fisheries and research vessels around the world (e.g. Davis 2002, Broadhurst et al. 2006, Uhlmann and Broadhurst 2015). Reliable information on survival of discarded specimens is essential for several reasons. First, regarding the Landing Obligation, the survival of unwanted animals following capture and discarding needs to be evaluated to determine whether by-catch should be landed or may be discarded. For example, a "high survivability" exemption was granted in 2016 for the Norway lobster (Nephrops norvegicus) because scientific evidence indicated high discard survival rates (EU 2015). With respect to stock assessment, the inclusion of estimates of discard mortality reduces uncertainty in estimates of total fishing mortality (e.g. Breen and Cook 2002), and therefore provides more reliable estimates of maximum sustainable yield and other biological reference points. In biological terms, investigating the probable fate of discards is important for understanding the extent to which fishing activities alter the trophic webs in the marine environment (Castro et al. 2005). Moreover, determining influential factors on survival of a species allows a better understanding of the stressors associated with capture, handling and discarding, and thus enables strategies to improve survival to be developed.
The Algarve deep-water trawl fishery targets three main crustacean species (Parapenaeus longirostris, $\mathrm{Ne}$ phrops norvegicus and Aristeus antennatus) at fishing depths of between 200 and $700 \mathrm{~m}$. The crustacean trawlers have licences for two separate mesh size categories: a 55 to $59 \mathrm{~mm}$ mesh size when they are targeting red and rose shrimp species, which must compose $30 \%$ of total catch; and a $70 \mathrm{~mm}$ mesh size when they are targeting Norway lobster, without by-catch limitations. Blue whiting (Micromesistius poutassou) is the most discarded species by weight, but it is not included in the 70\% maximum limit for by-catch species (Diário da República 2000, Monteiro et al. 2001). Previous work has shown discard rates of approximately $70 \%$ in crustacean trawlers, meaning the weight of by-catch is substantially larger than the weight of target species (Costa et al. 2008, Monteiro et al. 2001). The main discarded fish species are blue whiting (Micromesistius poutassou), European hake (Merluccius merluccius), Atlantic horse mackerel (Trachurus trachurus), blue jack mackerel (Trachurus picturatus), conger eel (Conger conger) and shark species (Scyliorhinus canicula, Galeus melastomus, Etmopterus spp.) (Borges et al. 2001, Erzini et al. 2002). For the Portuguese fisheries, several studies of post-release survival of discarded fish and invertebrate species have been conducted recently. Survival of N. norvegicus caught with trawlers and placed into cages ranged between $12.5 \%$ and $60 \%$ (Castro et al. 2003). By contrast, for individuals initially caught by traps, the mean survival rate was $86 \%$ (Campos et al. 2015). Survival experiments of by-catch fish (Trachinus vipera, Dicologlossa cuneata) and crab (Polybius henslowii) from bivalve dredges showed that $54 \%$ to $81 \%$ of the individuals died after 48 hours in captivity (Leitão et al. 2014). No studies have yet been done on the survival of by-catch fish species in demersal trawlers in Portuguese waters.

Discard survival assessments can be conducted using three different methods: vitality assessment, which gives estimates of immediate mortality; captive observation; and tagging/biotelemetry (ICES 2014, Breen and Catchpole in press). Detailed and prolonged assessments of discard mortality obtained by captive observation and tagging are costly, technically difficult to acquire, and only available for a limited number of species and fisheries (e.g. Laptikhovsky 2004, Huse and Vold 2010, Campos et al. 2015). Vitality assessments, in the form of semi-quantitative indicators and time-to-mortality (TTM, a coarse mortality indicator) estimates, can give cost-effective preliminary assessments, allowing prioritization of in-depth assessments on the most resilient species (ICES 2014, Breen and Catchpole in press). Captive observation consists of transferring wild-caught animals (before being discarded) into tanks or other holding facilities (e.g. underwater cages) and monitoring them until the mortality rate stabilizes, which might take days to weeks. This approach should be representative of real fishing conditions and, when combined with vitality assessments, can give reliable estimates of survival 
rate (excluding predation) that are illustrative of the particular fishery and species of interest (ICES 2014).

This study had three main goals. The first was to estimate immediate mortality and prioritise species that may survive the discarding process, using vitality assessments and TTM. The second was to analyse the effect of biological traits (e.g. size, presence and type of gas bladder, scales, injuries and metabolic rate) on TTM, since these largely determine the susceptibility of a species to dying after being caught and discarded. The third was to make a captive observation survival assessment, in which individual conger eels (Conger conger) were held in tanks to estimate the mortality rate. This included a description of the types and frequencies of injuries and how these related to the observed mortality.

\section{MATERIALS AND METHODS}

\section{By-catch mortality after air exposure}

Sampling was conducted in December 2016 (during six days) and February 2017 (five days' duration) in a commercial trawler along the south coast of Portugal (Fig. 1). Positional data (latitude and longitude), depth and fishing operation details were recorded. The trawl gear was towed for $4 \mathrm{~h}(95 \% \mathrm{CI}: 3.6$ to $5.2 \mathrm{~h}$ ), at depths of between 123 and $841 \mathrm{~m}$. Speed of individual tows was 2.9 to 3 knots (given by the skipper), and mean hauling time was 20 min $(95 \%$ CI: 16.4 to $23 \mathrm{~min}$ ). The cod end was emptied into a holding container below deck and, in most hauls, immediately set again (prior to catch sorting); this time between re-deploying the net and starting to sort the catch lasted around seven min. The sorting process took on average $18 \mathrm{~min}$ (95\% CI: 15.6 to $20 \mathrm{~min}$ ). Time 0 was defined as when the catch was dropped into the holding container. The crew sorted the catch by hand and samples were taken immediately after the sorting process started.

For TTM monitoring, samples of 10 to 15 individuals of each species were collected randomly, depending on the by-catch composition of the haul. After the initial injury evaluation, individual animals were monitored for out-of-water vitality assessment (Table 1) at regular intervals for 2-3 s, until there were no signs of life. Injuries were classified into four types (scale loss,

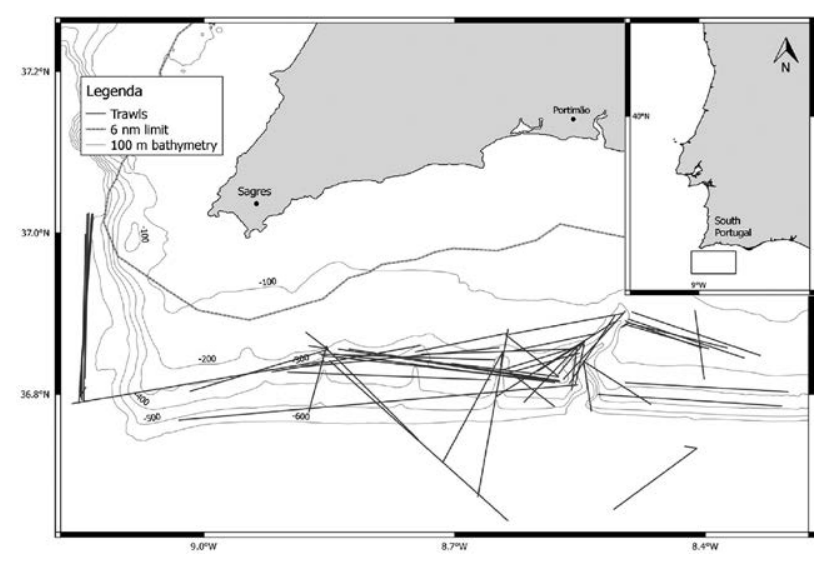

Fig. 1. - Location of the study area off South Portugal (Algarve) where the trawls were performed (dark grey lines). The dashed line represents the 6 minimum nautical mile limit of fishing for trawlers. The light grey lines represent the bathymetry every $100 \mathrm{~m}$ depth.

bruises, wounding and deep wounding; Catchpole et al. 2015) and recorded only if there was clear damage. Immobile individuals were manipulated and tested for reflex responses to determine whether they were dead (if at least one of the reflexes was present, the individual was considered to be alive; Table 2). Total body length was measured in centimetres.

\section{Biological traits}

This work considered the biological characteristics of each species: body size, deciduous scales, injuries, presence and type of gas bladder and metabolic rates. This information was compiled from general literature and field observations; when detailed information was not available, species were given the same trait category as other species within their family or order (Jacobsen et al. 2002, Revill et al. 2005). The justification for the inclusion of these biological covariates is presented in the following.

\section{Body length}

Fish of smaller size are likely to be more susceptible to hypoxia due to their increased mass-specific metabolic rates and consequently higher energy expenditures in breathing activities (Benoît et al. 2013).

Table 1. - Vitality states/scores with descriptions of qualifying criteria (adapted from Benoît et al. 2010).

\begin{tabular}{lcl}
\hline \multicolumn{1}{c}{ Vitality state } & Score & Description \\
\hline Excellent & 1 & Vigorous body movement without stimuli \\
Good & 2 & Weak body movement but responds to touching \\
Poor & 3 & No body movement, no obvious response to stimuli but fish can move operculum/mouth/fins \\
Dead/moribund & 4 & No body or opercular movements, no response to touching or grabbing \\
\hline
\end{tabular}

Table 2. - Reflex responses tested out of water, with a description of the implemented stimuli and expected responses if the reflex was present (adapted from Catchpole et al. 2015 and Davis 2010).

\begin{tabular}{lll}
\hline Out-of-water reflex & \multicolumn{1}{c}{ Stimulus action } & \multicolumn{1}{c}{ Reflex response } \\
\hline Operculum closure & $\begin{array}{l}\text { The operculum of the fish is gently opened with a } \\
\text { blunt object } \\
\text { The mouth of the fish is gently opened with a blunt } \\
\text { object }\end{array}$ & $\begin{array}{l}\text { Ability to tightly close/clamp its operculum after being } \\
\text { opened within 5 seconds } \\
\text { Ability to tightly close/clamp its mouth after being } \\
\text { opened within 5 seconds }\end{array}$ \\
Gag response & $\begin{array}{l}\text { A blunt object is inserted in the mouth of the fish and } \\
\text { touch the throat }\end{array}$ & Fish gagged/vomit \\
\hline
\end{tabular}


Table 3. - Reflex responses tested in water, with a description of the implemented stimuli and expected responses if the reflex was present (adapted from Catchpole et al. 2015 and Davis 2010).

\begin{tabular}{lll}
\hline \multicolumn{1}{c}{ In-water reflex } & \multicolumn{1}{c}{ Stimulus action } & \multicolumn{1}{c}{ Reflex response } \\
\hline Startle touch & $\begin{array}{l}\text { Fish is underwater and hand approaches to touch } \\
\text { fish }\end{array}$ & Actively moves away before or at first touch \\
Tail grab & Fish is grabbed gently by its tail & Actively struggles to escape within 5 seconds \\
Orientation/righting & $\begin{array}{l}\text { Fish is held on the palm of the hand on its back just } \\
\text { below the water surface and released }\end{array}$ & Actively rights itself underwater within 5 seconds \\
\hline
\end{tabular}

\section{Gas bladder}

Physoclistous species that possess a gas bladder, with no connection between bladder and gut, suffer significantly increased mortality due to depressurization when fish are brought to surface, resulting in extrusion of internal organs and the rupture of the gas bladder (Benoît et al. 2013). Other species with physostomous bladders (i.e. open bladders, where there is a connection to the gut) can better regulate gas pressure and therefore depressurization may not have such severe effects. For individuals without a swim bladder, it is assumed that depressurization effects would be less damaging (Broadhurst et al. 2006).

\section{Deciduous scales}

Deciduous scales that are easily lost are a biological trait that could increase susceptibility to injury and desiccation when fish are exposed to the stressors during capture, as well as when they are exposed to air after capture and handling (Broadhurst et al. 2006, Benoît et al. 2013).

\section{Metabolic rate}

Low metabolic rates of sedentary species, as a strategy to conserve energy, are associated with increased resistance to stress (Carlson et al. 2004, Helfman et al. 2009). Where species specific metabolic rate values were not available, data from related taxa were used as an alternative (Yang et al. 1992, Cowles and Childress 1995, Clarke and Johnston 1999).

\section{Survival assessment}

A survival assessment of conger eel (Conger conger) was conducted from 23 to 27 July 2017 on a commercial bottom trawler targeting deep-water crustaceans. Once the net was emptied to the holding container below deck and sorting of the catch started, 20 to 30 individuals were collected from each haul and placed in observation tanks (first haul - tank 1; second haul - tank 2). Tank 1 was made of steel, had approximately 650-L capacity and included a cooling system. Tank 2 was made of plastic and had approximately $500-\mathrm{L}$ capacity. It was not possible to have a continuous water flow, but the water in the tanks was completely renewed every $3 \mathrm{~h}$, using a seawater inlet and a small water pump to transfer cooled water from tank 1 to tank 2 . Water temperature in the tanks ranged between $13^{\circ} \mathrm{C}$ and $18^{\circ} \mathrm{C}$. The fish were held in the tanks for $65 \mathrm{~h}$ and monitored every 4 to $6 \mathrm{~h}$; when dead, fish were removed and recorded. Swimming behaviour was monitored at the start and during the assessment. Major injuries were noted at the end of the assessment: scratches, deep cuts, wounds or bruises (scored as presence/absence, 1/0). In-water reflexes were tested to confirm the vitality/survival status at the start and at the end of the assessment (scored as 1, present if a response was clearly present or 0 , absent if the response was not present or weak; Table 3).

\section{Data analysis}

Vitality and TTM data were analysed using the survival package in $\mathrm{R}$ to model survival probability as a function of time, as a measure of fish tolerance to stress and air exposure (Therneau 2016). Non-parametric Kaplan-Meier models were fitted to the TTM data to estimate time to $50 \%$ mortality after data censoring. Data censoring occurs when the exact time of an event (t), in this case time of mortality after capture and handling, is not known (Benoît et al. 2013). Fish that were dead (score four on vitality assessment) when first observed at time 0 (before the monitoring period started) were treated as left-censored observations in that their actual time of mortality occurred before the observation time $(\mathrm{T})$. Fish that were still alive when monitoring ceased were considered rightcensored observations $(\mathrm{t}>\mathrm{T})$; the remaining individuals (i.e. those that died during TTM monitoring) were considered uncensored observations $(\mathrm{t} \approx \mathrm{T})$.

In addition, interval censoring was applied when mortality was known to occur between two times $\left(\mathrm{T}_{\mathrm{i}}<\mathrm{t}<\mathrm{T}_{\mathrm{j}}\right)$ but the exact time of mortality was not observed. This type of censoring was used specifically to combine TTM data for the 12 taxa, for analysis of biological traits. With regard to classifying biological traits, the gas bladder had three categories: absence of gas bladder, open gas bladder and closed gas bladder. Deciduous scales and injuries were defined as present or absent. Metabolic rate had three classes, according to the range of values found for the group of taxa: low ( $<3 \mathrm{mg} \mathrm{O}_{2} \mathrm{~h}^{-1}$ per $50 \mathrm{~g}$ body mass), medium (3-6 mg $\mathrm{O}_{2} \mathrm{~h}^{-1}$ per $50 \mathrm{~g}$ body mass) and high metabolic rate ( $>6$ $\mathrm{mg} \mathrm{O}_{2} \mathrm{~h}^{-1}$ per $50 \mathrm{~g}$ body mass). Information on metabolic rate from different sources was standardized as milligrams of oxygen consumed per hour per 50 grams of body mass, assuming oxygen solubility $7.9 \mathrm{mg} \mathrm{L}^{-1}$ or $5.9 \mathrm{~mL} \mathrm{~L}^{-1}$ at salinity of 35 , pressure of 1 bar and water temperature of $15^{\circ} \mathrm{C}$.

Parametric Weibull models were used to correlate survival probability (from TTM estimates) with vitality at first observation, individual size and respective biological traits. The number of injuries to each individual 


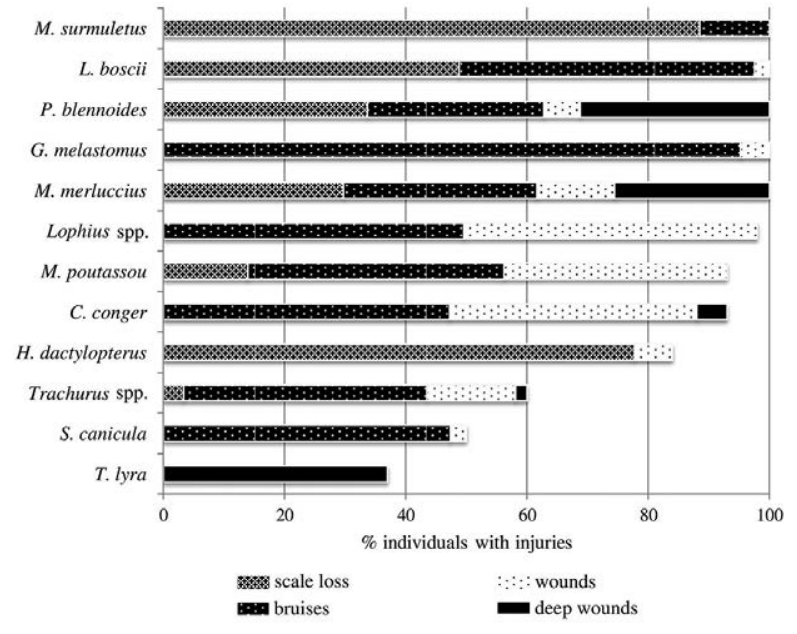

Fig. 2. - Percentage (\%) of individuals with four types of injuries (scale loss, bruises, wounds and deep wounds) for each species.

animal was included as a possible explanatory variable of the mortality results in a Weibull model. Regarding the survival assessment, a log-rank test compared the survival estimates between the two tanks. The Akaike information criterion (AIC) was calculated to give the goodness-of-fit of each model and log-likelihood ratio tests performed to test whether there were significant differences when different models were compared.

\section{RESULTS}

\section{By-catch mortality after air exposure}

Data on TTM were collected for a total of 451 individuals belonging to 14 species from 40 hauls. Trachurus trachurus, T. picturatus, Lophius piscatorius and L. budegassa were grouped by genera, i.e. mackerel species and monkfish species, respectively. In the examination of injuries, more than $80 \%$ of the individuals in each taxon showed some form of injury, except mackerel species (Trachurus spp.), lesser-spotted dogfish (Scyliorhinus canicula) and piper gurnard (Trigla lyra; Fig. 2). European hake (Merluccius merluccius), greater forkbeard (Phycis blennoides) and piper gurnard often exhibited severe forms of damage: i.e. inflated gas bladder and eversion of stomach (personal observations). The blackmouth catshark (Galeus melastomus) and spotted dogfish often had bruises on the skin. Most fish with scales (surmullet, Mullus surmuletus; four-spot megrim, Lepidorhombus boscii; greater forkbeard; European hake; blue whiting, Micromesistius poutassou; and blackbelly rosefish, Helicolenus dactylopterus) had scale loss during the capturing and handling process; mackerel species and piper gurnard were the exceptions and conserved their scales. Mackerel species and conger eel frequently had bruises on the pectoral fins, and the latter also appeared scratched.

Kaplan-Meier models were applied individually for the 12 taxa (blue whiting, greater forkbeard, fourspot megrim, piper gurnard, European hake, surmullet, mackerel species, blackbelly rosefish, blackmouth catshark, lesser-spotted dogfish, monkfish species and conger eel) to calculate time to $50 \%$ mortality (examples of hake, spotted dogfish and mackerel in Fig. 3). There were two highly resistant species, spotted dogfish and conger eel, with mean times to $50 \%$ mortality of over $100 \mathrm{~min}$ (Fig. 4). In fact, these two species, together with blackbelly rosefish, were the only ones that had right-censored observations.

Not all vitality categories were observed in every species. For instance, vitality 1 was not recorded for spotted dogfish, and neither vitality 1 nor 2 was observed for monkfish species, blackmouth catshark, European hake, piper gurnard, blue whiting and greater forkbeard. Regarding the Weibull model results for blackbelly rosefish, conger eel and mackerel species, low vitality categories ( 3 and 4 , Table 4 ) have a positive or less negative effect on TTM when compared with vitality 1 and 2 , although this effect was only significant for mackerel species. Individual animal size had a significant effect on TTM for spotted dogfish and conger eel, in which smaller individuals died at a faster rate than larger ones.
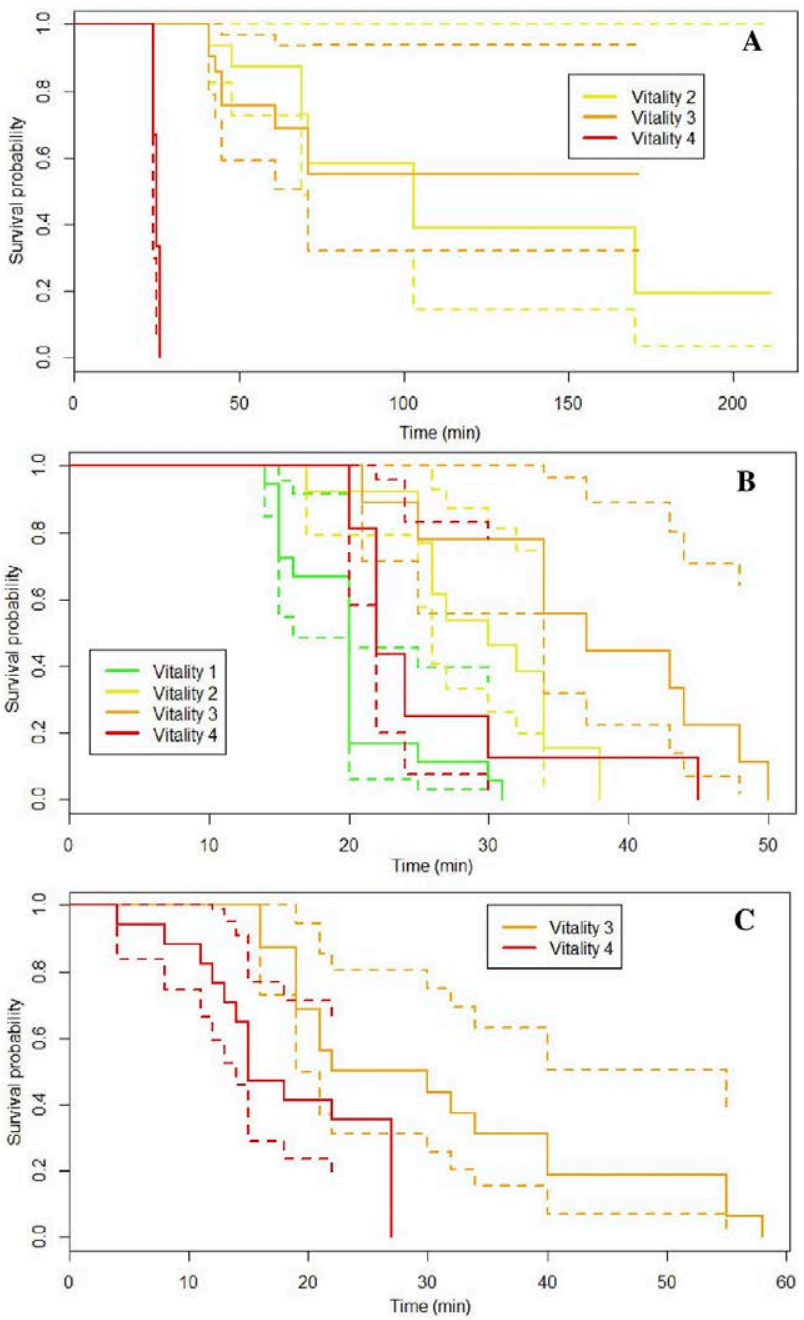

Fig. 3. - Results of Kaplan-Meier for Scyliorhinus canicula (A), Trachurus spp. (B) and Merluccius merluccius (C), with survival curves for each vitality category. Dashed lines represent $95 \%$ confidence intervals. 


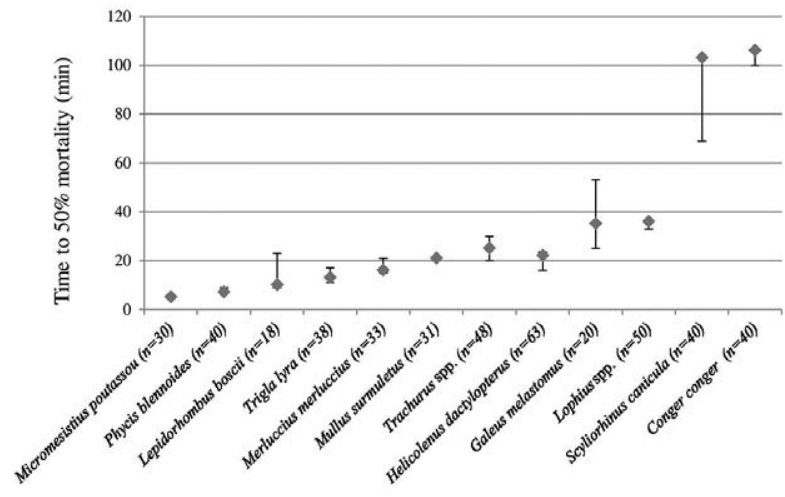

Fig. 4 - Time to $50 \%$ mortality for the species included in the analysis. Error bars represent $95 \%$ confidence intervals.

\section{Biological trait analysis}

Not all the biological traits had relevant effects: injuries appeared to have no influence on TTM for these species, despite improving the fit of the base model (Table 5). By contrast, deciduous scales and closed gas bladder significantly reduced TTM results ( $\mathrm{p}$-values $<0.0001$ ). Low metabolic rates and open gas bladder significantly increased TTM.

\section{Survival assessment}

Overall, 64 fish from 2 tows, maintained in different tanks, were used in the survival analysis. In tank 1, 4 out of 36 fish died during the monitoring period, giving a survival rate of $88.9 \%(95 \% \mathrm{CI}$ : $78.6 \%$ to $99.2 \%$ ). In the second tank, 6 fish died (from a total of 28 fish), giving a survival rate of $78.6 \%$ (95\% CI: $63.4 \%$ to $93.8 \%$ ) at the end of the observation period. Most mortality occurred in the first $14 \mathrm{~h}: 8.3 \%$ in tank 1 (95\% CI: $0.7 \%$ to $17.4 \%)$ and $17.9 \%$ in tank II (95\%

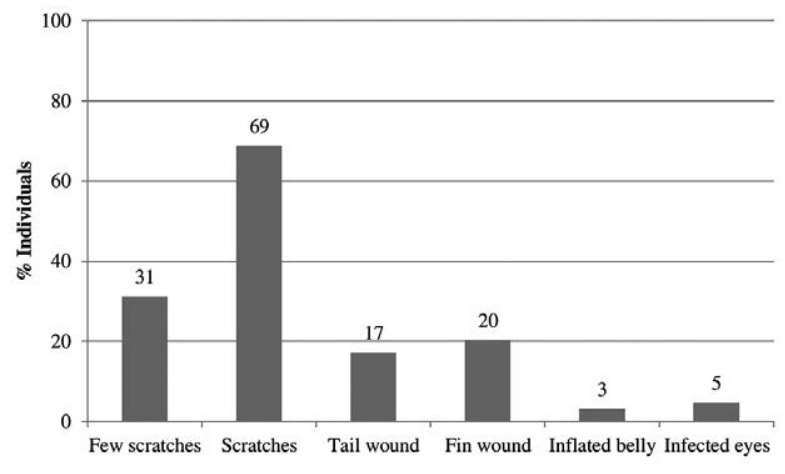

Fig. 5. - Frequency of injuries shown as percentage (\%) of individuals with each type of injury in Conger conger.

CI: $3.7 \%$ to $32.0 \%$ ). However, the mortality rate did not stabilize at the end of the 65 -h observation period.

A comparison of survival results between the two tanks showed no significant differences, so the data were grouped into one survival curve corresponding to an overall survival probability of $84.4 \%$ (95\% CI: $75.5 \%$ to $93.3 \%$ ). All fish started to swim immediately after being placed in water and $98 \%$ responded positively to the tested in-water reflexes.

Every individual had some form of injury, from shallow scratches on the surface of the skin to more severe ones, e.g. deep wounds in tail and fins. The frequency of injuries is shown in Figure 5, with almost $70 \%$ of conger eel exhibiting scratched skin, likely due to physical contact and crowding inside the trawl. Around $40 \%$ of the fish had bruises on the tail and pectoral fins; $5 \%$ had eye injuries; and 3\% showed inflated abdomens, a probable sign of barotrauma.

The number of injuries to each individual was included as a covariable in a Weibull model to test whether the presence of injuries influenced the observed mortality. Only the simultaneous presence of

Table 4. - Coefficients and p-values from Weibull models for Scyliorhinus canicula, Helicolenus dactylopterus, Conger conger, Lophius spp. and Trachurus spp. with vitality and size as possible explanatory variables for time-to-mortality. "Coeff.", coefficient estimates for the relationship between vitality category and time-to-mortality; if positive, vitality is directly correlated with TTM; if negative, vitality is inversely correlated with TTM. "AIC diff", difference in AIC values in comparison with the base model (without covariates). Significance level $\alpha=0.05$.

\begin{tabular}{|c|c|c|c|c|c|c|c|c|c|c|}
\hline \multirow[t]{2}{*}{ Weibull models } & \multicolumn{2}{|c|}{ S. canicula } & \multicolumn{2}{|c|}{ H. dactylopterus } & \multicolumn{2}{|c|}{ C. conger } & \multicolumn{2}{|c|}{ Lophius spp. } & \multicolumn{2}{|c|}{ Trachurus spp. } \\
\hline & Coeff. & p-value & Coeff. & p-value & Coeff. & p-value & Coeff. & p-value & Coeff. & p-value \\
\hline Vitality 2 & - & - & -0.39 & 0.28 & 0.20 & 0.21 & - & & 0.37 & $<0.0001$ \\
\hline Vitality 3 & -0.27 & 0.29 & -0.17 & 0.65 & 0.20 & 0.26 & - & & 0.63 & $<0.0001$ \\
\hline Vitality 4 & -1.78 & $<0.0001$ & -1.41 & 0.99 & -1.01 & $<0.0001$ & -1.88 & 0.98 & 0.33 & 0.001 \\
\hline AIC diff & -9.7 & 0.001 & -19.9 & $<0.0001$ & -4.2 & 0.017 & -75.2 & $<0.0001$ & -25.3 & $<0.0001$ \\
\hline Size & 0.07 & $<0.0001$ & 0.023 & 0.17 & 0.01 & 0.025 & - & - & - & - \\
\hline AIC diff & -20 & $<0.0001$ & +0.3 & 0.19 & -3.6 & 0.018 & - & - & - & - \\
\hline
\end{tabular}

Table 5. - Coefficients, AIC and p-values from Weibull models of time-to-mortality for 12 species, without covariates (base model) and models including each biological trait as possible explanatory variable for time-to-mortality. Significance level $\alpha=0.05$.

\begin{tabular}{|c|c|c|c|c|c|}
\hline \multirow[t]{2}{*}{ Parameters } & & \multicolumn{2}{|c|}{ Base model } & \multirow[t]{2}{*}{ AIC } & \multirow[t]{2}{*}{ p-value likelihood test } \\
\hline & & Coeff. & $\mathrm{p}$-value & & \\
\hline \multirow{5}{*}{$\begin{array}{l}\text { Intercept } \\
+ \text { Injury } \\
+ \text { Gas bladder (no bladder) }\end{array}$} & & 3.16 & 0.00 & 1648 & - \\
\hline & & 0.23 & 0.14 & 1387 & $<0.0001$ \\
\hline & & & & 1528 & $<0.0001$ \\
\hline & Open gas bladder & 0.22 & 0.03 & & \\
\hline & Closed gas bladder & -0.88 & $<0.0001$ & & \\
\hline \multirow{4}{*}{$\begin{array}{l}\text { + Scales } \\
\text { + Metabolic rate (high) }\end{array}$} & & -1.16 & $<0.0001$ & 1419 & $<0.0001$ \\
\hline & & & & 1378 & $<0.0001$ \\
\hline & Low & 1.61 & $<0.0001$ & & \\
\hline & Medium & 0.59 & $<0.0001$ & & \\
\hline
\end{tabular}


Table 6. - Results of Weibull model for survival of Conger conger, without covariates (base model) and model including number of injuries as possible explanatory variable for observed mortality. Significance level $\alpha=0.05$.

\begin{tabular}{|c|c|c|c|}
\hline \multirow{2}{*}{ Parameters/models } & \multicolumn{2}{|c|}{ Base model } & \multirow{2}{*}{$\begin{array}{c}\mathrm{p} \text {-value } \\
\text { likelihood test }\end{array}$} \\
\hline & Coeff. & p-value & \\
\hline \multirow{3}{*}{$\begin{array}{l}\text { Intercept } \\
\text { AIC (base model) } \\
+ \text { Number of injuries (1) }\end{array}$} & 6.62 & $<0.0001$ & - \\
\hline & \multirow{2}{*}{\multicolumn{2}{|c|}{140}} & \\
\hline & & & 0.038 \\
\hline 0 injuries & 1.38 & 0.34 & \\
\hline 2 injuries & 0.35 & 0.71 & \\
\hline 3 injuries & -0.32 & 0.01 & \\
\hline AIC & \multicolumn{2}{|c|}{138} & \\
\hline
\end{tabular}

at least three types of injuries significantly increased mortality $($ coefficient $=-0.32 ;$-value $=0.01$; Table 6).

\section{DISCUSSION}

This study provides four main contributions for a better understanding of discard mortality, including an improved methodological approach to assessing vitality.

First, a preliminary evaluation of the by-catch vulnerability can be attained through TTM and KM results. These identify blue whiting (Micromesistius poutassou), greater forkbeard (Phycis blennoides), four-spot megrim (Lepidorhombus boscii), piper gurnard (Trigla lyra), European hake (Merluccius merluccius), surmullet (Mullus surmuletus), mackerel (Trachurus spp.) and blackbelly rosefish (Helicolenus dactylopterus) as highly susceptible to air exposure; with 50\% TTMs of less than $30 \mathrm{~min}$, and in most cases less than $20 \mathrm{~min}$. Blackmouth catshark (Galeus melastomus) and monkfish species (Lophius piscatorius and L. budegassa) were more resilient, with $50 \%$ TTMs close to $40 \mathrm{~min}$. However, considering the types and extent of injuries observed, the majority of by-catch fish species are fragile and do not cope well with the stressors associated with capture, handling and discarding. Only crustacean, bivalve, echinoderm and elasmobranch species are likely to survive, but these also account for a low percentage of discarded weight (Hill and Wassenberg 2000, Monteiro et al. 2001, Depestele et al. 2014). The only species that demonstrated strong resilience were spotted dogfish (Scyliohinus canicula) and conger eel (Conger conger), with 50\% TTMs in excess of $100 \mathrm{~min}$. These vitality assessments were conducted only during winter months (December and January) when air and water temperatures are lower than in summer. Therefore, if these experiments were replicated in warmer months, mortality rates would probably be higher due to increased thermal stress, increased air temperatures and faster desiccation (Benoît et al. 2013, ICES 2014). However, water to air temperature differences were not included in this study as an influential variable because priority was given to the assessment of short-term survival of conger eel during summer months.

The second finding of this study was the confirmation that there were particular biological traits that affected TTM and thus the susceptibility of a species to capture and handling related stressors. Body size was a significant explanatory variable for spotted dogfish and conger eel which endured long periods of air exposure.
Physoclistous fish (with a closed gas bladder) died at a faster rate than physostomous fish (with a gas bladder connected to the digestive tract). Physoclistous fish cannot resist depressurization effects when brought to surface quickly. Hauling occurred at sufficiently high speeds ( $20 \mathrm{~m}$ per $\mathrm{min})$ to cause over-inflation or rupturing of the swim bladder, and consequently release of gas into the body cavity and eversion of stomach and gut (Rummer and Bennett 2005, Nichol and Chilton 2006). Furthermore, presence of deciduous scales and high metabolic rates significantly decreased TTM. Fish with deciduous scales are more vulnerable to water losses due to scale loss and consequential impairment of the osmoregulatory functions of the skin, resulting in increased sensitivity to hypoxia (Breen 2004, ICES 2014). These observations are in line with those of Benoît et al. (2013), in which mass-specific respiration demand, physoclistous bladders and deciduous scales all had significant and negative effects on survival. These authors also found that sedentariness was the most influential trait on TTM. In the present work, metabolic-rate-class can be considered comparable to sedentariness, and has a pronounced effect on how different fish species cope with the stressors related to hypoxia. Energy-conserving behaviour of low metabolic rates, characteristic of species such as monkfish and spotted dogfish, is translated into greater TTM results when compared with species with fast metabolism and high susceptibility to air exposure (e.g. surmullet, blue whiting). Injuries were not a significant factor for predicting mortality ( $\mathrm{p}$-value $>0.05)$, possibly because too few non-injured individuals were sampled (40 uninjured versus 367 with injuries).

The third result of this work was a short-term (65 h) survival estimate for conger eel, one of the two species identified in the preliminary vitality assessment with a high likelihood of survival, the other being spotted dogfish. Since spotted dogfish has been proved to have high survival (88\%; Revill et al. 2005, RodríguezCabello et al. 2005), it was decided to conduct the survival assessment on conger eel. At the end of the 65-h assessment, $84 \%$ of the conger eels survived (95\% CI: $75.5 \%$ to $93.3 \%$ ). This value is likely to be overestimated for two reasons: the mortality rate did not stabilize at the end of the experiment, and severe injuries were present in almost $70 \%$ of the individuals. Impaired fish have reduced ability to avoid predation and are more susceptible to physiological disturbances or disease (Davis 2002, Davis and Ottmar 2006, Davis 2010). In fact, individuals that showed more types of injuries had higher mortality. Besides, the assessment was conducted only in July, when temperature differences between fishing depth and surface waters were higher. However, seasonality was not considered in this study because the focus was on producing preliminary estimates of survival with novel approaches. For additional investigation of survival potential, inland tank trials are recommended in order to conduct a longer study, preferably using control fish. Analysis of cortisol, glucose and ions $\left(\mathrm{Na}^{+}, \mathrm{Cl}^{-}\right.$and $\left.\mathrm{K}^{+}\right)$from blood sampling can provide a method to study stress levels of fish in captivity (Marçalo et al. 2008). 
The fourth outcome is related to changing the methods used to evaluate vitality for this fishery. Based on the Kaplan-Meier and Weibull models, vitality at first observation is a poor predictor of TTM. Two major inconsistencies were identified: in some species states 1 and 2 are not present; in other species, high vitality scores (1 and 2) are associated with low TTM. Monkfish species, conger eel, spotted dogfish and blackmouth catshark are sedentary species; when subjected to extreme stressors, such as air exposure, these species reduce activity to a minimum in order to conserve energy. Consequently, vitality states 1 and 2 were never observed. The same was the case of four-spot megrim, European hake, piper gurnard and greater forkbeard. These species suffered decompression effects (i.e. barotrauma) and/or injuries which resulted in most individuals dying or arriving dead on deck (vitality state 3 and 4). In contrast, mackerel and surmullet displayed signs of intense activity and occasionally shivering movements when brought on deck; in accordance with the vitality scale, this response is "positive" and classified with high vitality scores for these species. But these signs seem to be an extreme stress-response. When placed in water, these individuals were unable to maintain orientation in the water (suffering a loss of equilibrium) and/or unable to swim (personal observations). These observations agreed with the substantially reduced TTM. Behavioural disturbances such as loss of equilibrium have been related to several stressors, one being air exposure (Davis 2005, Gingerich et al. 2007). Therefore, two separate vitality scales are proposed to adapt vitality assessment to the behaviour of benthic/ sedentary species and bathypelagic/fast swimming fish. For sedentary species, a combined methodology of vitality together with testing reflex actions (e.g. reflex action mortality predictors, RAMP; Davis 2007) better evaluates the overall state of the animal. In particular, the absence of a clear transition from alive to dead requires adaptions in the visual assessments. The solution is to use innate or reflex responses to precisely defined stimuli, such as the gag response or opening the operculum. As an example, Table 1 might be modified to include just three vitality states, complemented with response to reflex actions from Table 2 (vitality 1 , responds to all reflex actions; vitality 2 , responds to at least one reflex action; vitality 3 , no response to reflex actions). The vitality scale for bathypelagic and pelagic species should be supplemented, where possible, with testing reflex actions in water, recorded as presence (1) or absence ( 0 ) of the reflex response (Table 3 ).

In summary, this work provides cost-effective estimates of mortality for a wide range of species. It has also enabled the preliminary identification of species that might have a higher likelihood of surviving the discarding process. For this fishery, only two of the studied species seem to be resistant: spotted dogfish and conger eel. Further investigations should consider the survival of other phyla (e.g. molluscs or tunicates) and applicable solutions to improve survival (e.g. handling the catch with urgency and care, minimizing injuries and exposure to air). Finally, specific biological characteristics influenced not only mortality results but also the methodology used to reliably assess vitality. For future projects, the proposed modifications on vitality assessments should provide a cohesive methodology that takes into account species-specific traits.

\section{ACKNOWLEDGEMENTS}

We wish to thank Miguel Cunha, Alexandre Afonso and the captain and crew of the vessel Saturno of Testa $\&$ Cunhas for allowing the experimental work to be conducted on their facilities. This work was funded by the MINOUW project (ID 634495), co-funded by the Horizon 2020 Framework Programme of the European Union.

\section{REFERENCES}

Benoît H.P., Hurlbut T., Chassé J. 2010. Assessing the factors influencing discard mortality of demersal fishes using a semi-quantitative indicator of survival potential. Fish. Res. 106: 436-447. https://doi.org/10.1016/j.fishres.2010.09.018

Benoît H.P., Plante S., Kroiz M., et al. 2013. A comparative analysis of marine fish susceptibilities to discard mortality: effects of environmental factors, individual traits, and phylogeny. ICES J. Mar. Sci. 70: 99-113 https://doi.org/10.1093/icesjms/fss132

Borges T.C., Erzini K., Bentes L., et al. 2001. By-catch and discarding practices in five Algarve (southern Portugal) métiers. J. Appl. Ichtyol. 17: 104-114. https://doi.org/10.1111/j.1439-0426.2001.00283.x

Breen M. 2004. Investigating the mortality of fish escaping from towed fishing gears - a critical analysis. PhD thesis, Univ. Aberdeen, $332 \mathrm{pp}$.

Breen M., Cook R. 2002. Inclusion of discard and escape mortality estimates in stock assessment models and its likely impact on fisheries management. ICES CM 2002/V: 27, 15 pp.

Breen M., Catchpole. T. (eds) In press. ICES WKMEDS Guidance on Method for Estimating Discard Survival. ICES Coop. Res. Rep.

Broadhurst M.K., Suuronen P., Hulme A. 2006. Estimating collateral mortality from towed fishing gear. Fish Fish. 7: 180-218. https://doi.org/10.1111/j.1467-2979.2006.00213.x

Campos A., Fonseca P., Pilar-Fonseca T., et al. 2015. Survival of trawl-caught Norway lobster (Nephrops norvegicus L.) after capture and release - Potential effect of codend mesh type on survival. Fish. Res. 172: 415-422. https://doi.org/10.1016/j.fishres.2015.07.038

Carlson J.K., Goldman K.J., Lowe C.G. 2004. Metabolism, energetic demand and endothermy. In: Carrier J.C., Musick J.A., Heithaus M.R. (eds), Biology of sharks and their relatives. CRC Press, New York, pp. 203-219. https://doi.org/10.1201/9780203491317.ch7

Castro M., Araújo A., Monteiro P., et al. 2003. The efficacy of releasing caught Nephrops as a management measure. Fish. Res. 65: 475-484. https://doi.org/10.1016/j.fishres.2003.09.033

Castro M., Araújo A., Monteiro P. 2005. Fate of discards from deep water crustacean trawl fishery off the south coast of Portugal. N. Z. J. Mar. Fresh. Res. 39: 437-446. https://doi.org/10.1080/00288330.2005.9517323

Catchpole T., Randall P., Forster R., et al. 2015. Estimating the discard survival rates of selected commercial fish species (plaice - Pleuronectes platessa) in four English fisheries (MF1234), Cefas Rep., London, 108 pp.

Clark M.R., Althaus F., Schlacher T.A., et al. 2015. The impacts of deep-sea fisheries on benthic communities: a review. ICES J. Mar. Sci. 73: 51-69 https://doi.org/10.1093/icesjms/fsv123

Clarke A., Johnston N.M. 1999. Scaling of metabolic rate with body mass and temperature in teleost fish. J. Anim. Ecol. 68: 893-905. https://doi.org/10.1046/j.1365-2656.1999.00337.x

Costa M.E., Erzini K., Borges T.C. 2008. Bycatch of crustacean and fish bottom trawl fisheries from southern Portugal (Algarve). Sci. Mar. 72: 801-814. 
Cowles D.L., Childress J.J. 1995. Aerobic metabolism of the anglerfish Melanocetus johnsoni, a deep-pelagic marine sit-and-wait predator. Deep-Sea Res. 42: 1631-1638. https://doi.org/10.1016/0967-0637(95)00061-A

Davis M.W. 2002. Key principles for understanding fish bycatch discard mortality. Can. J. Fish. Aquat. Sci. 59: 1834-1843. https://doi.org/10.1139/f02-139

Davis M.W. 2005. Behaviour impairment in captured and released sablefish: ecological consequences and possible substitute measures for delayed discard mortality. J. Fish Biol. 66: 254-265. https://doi.org/10.1111/j.0022-1112.2005.00602.x

Davis M.W. 2007. Simulated fishing experiments for predicting delayed mortality rates using reflex impairment in restrained fish. ICES J. Mar. Sci. 64: 1535-1542. https://doi.org/10.1093/icesjms/fsm087

Davis M.W. 2010. Fish stress and mortality can be predicted using reflex impairment. Fish Fish. 11: 1-11. https://doi.org/10.1111/j.1467-2979.2009.00331.x

Davis M.W., Ottmar M.L. 2006. Wounding and reflex impairment may be predictors for mortality in discarded or escaped fish. Fish. Res. 82: 1-6. https://doi.org/10.1016/j.fishres.2006.09.004

Depestele J., Desender M., Benoît H.P., et al. 2014. Short-term survival of discarded target fish and non-target invertebrate species in the "eurocutter" beam trawl fishery of the southern North Sea. Fish. Res. 154: 82-92. https://doi.org/10.1016/j.fishres.2014.01.018

Diário da República. 2000. Portaria n ${ }^{\circ}$ 1102-E/2000 de 22 de Novembro

https://www.marinha.pt/conteudos_externos/lex$\mathrm{mar} / \mathrm{PGPAT} \% 20100 / \mathrm{PG}$ P A T \% $201000 \% 20-\% 20$ Cap\%C3\%ADtulos/Cap\%C3\%ADtulo\%20B\%20Pesca/ Sub-cap \%C3\%ADtulo\%20B.3/Portaria\%201102-C-2000\%20 (22NOV2000).pdf

Erzini K., Costa M.E., Bentes L., et al. 2002. A comparative study of the species composition of discards from five fisheries from the Algarve (southern Portugal). Fish. Manage. Ecol. 9: 31-40. https://doi.org/10.1046/j.1365-2400.2002.00284.x

European Union (EU). 2013. Regulation (EU) No 1380/2013 of the European Parliament and of the Council of 11 December 2013 on the Common Fisheries Policy, amending Council Regulations (EC) No 1954/2004 and (EC) No 1224/2009 and repealing Council Regulations (EC) No 2371/2002 and (EC) No 639/2004 and Council Decision 2004/585/EC. Off. J. Europ. Union L 354/22.

European Union (EU). 2015. Commission Delegated Regulation (EU) $2015 / 2439$ of 12 October 2015 establishing a discard plan for certain demersal fisheries in south-western waters. Off. J. Europ. Union L 336/36.

Gingerich A.J., Cooke S.J., Hanson K.C., et al. 2007. Evaluation of the interactive effects of air exposure duration and water temperature on the condition and survival of angled and released fish. Fish. Res. 86: 169-178. https://doi.org/10.1016/j.fishres.2007.06.002

Helfman G.S., Collete B.B., Facey D.E., et al. 2009. The diversity of fishes - Biology, evolution and ecology. Second edition. WileyBlackwell, West Sussex.

Hill B.J., Wassenberg T.J. 2000. The probable fate of discards from prawn trawlers fishing near coral reefs - A study in the northern Great Barrier Reef, Australia. Fish. Res. 48: 277-286.
https://doi.org/10.1016/S0165-7836(00)00185-5

Huse I., Vold A. 2010. Mortality of mackerel (Scomber scombrus L.) after pursing and slipping from a purse seine. Fish. Res. 106: 54-59.

https://doi.org/10.1016/j.fishres.2010.07.001

ICES. 2014. Report of the Workshop on Methods for Estimating Discard Survival (WKMEDS), 17-21 February 2014, ICES HQ, Copenhagen, Denmark. ICES CM 2014/ACOM:51, 114 pp.

Jacobsen J.A., Jákupsstovu S.H., Poulsen M., et al. 2002. Does the seasonal variation in fat content of blue whiting affect the acoustic conversion factor (TS)? ICES CM 2002/O:15, Theme session $\mathrm{O}, 8 \mathrm{pp}$.

Kelleher K. 2005. Discards in the world's marine fisheries. An update. FAO Fish. Tech. Pap. 470, Rome, 131 pp.

Laptikhovsky V.V. 2004. Survival rates for rays discarded by the bottom trawl squid fishery off the Falkland Islands. Fish. Bull. 102: 757-759.

Leitão F., Range P., Gaspar M.B. 2014. Survival estimates of bycatch individuals discarded from bivalve dredges. Braz. J. Oceanogr. 62: 257-263. https://doi.org/10.1590/s1679-87592014067006204

Marçalo A., Pousão-Ferreira P., Mateus L., et al. 2008. Sardine early survival, physical condition and stress after introduction to captivity. J. Fish Biol. 72: 103-120. https://doi.org/10.1111/j.1095-8649.2007.01660.x

Monteiro P., Araújo A., Erzini K., et al. 2001. Discards of the Algarve (southern Portugal) crustacean trawl fishery. Hydrobiologia 449: 267-277. https://doi.org/10.1023/A:1017575429808

Nichol D.G., Chilton E.A. 2006. Recuperation and behaviour of Pacific cod after barotrauma. ICES J. Mar. Sci. 63: 83-94. https://doi.org/10.1016/j.icesjms.2005.05.021

Pusceddu A., Bianchelli S., Martín J., et al. 2014. Chronic and intensive bottom trawling impairs deep-sea biodiversity and ecosystem functioning. PNAS 111: 8861-8866. https://doi.org/10.1073/pnas.1405454111

Revill A.S., Dulvy N.K., Holst R. 2005. The survival of discarded lesser-spotted dogfish (Scyliorhinus canicula) in the Western English Channel beam trawl fishery. Short communication. Fish. Res. 71: 121-124. https://doi.org/10.1016/j.fishres.2004.07.006

Rodríguez-Cabello C., Fernández A., Olaso I., et al. 2005. Survival of small-spotted catshark (Scyliorhinus canicula) discarded by trawlers in the Cantabrian Sea. J. Mar. Biol. Ass. U.K. 85: 1145-1150. https://doi.org/10.1017/S002531540501221X

Rummer J.L., Bennet W.A. 2005. Physiological effects of swim bladder overexpansion and catastrophic decompression on red snapper. Trans. Am. Fish. Soc. 134: 1457-1470. https://doi.org/10.1577/T04-235.1

Therneau T. 2016. A Package for Survival Analysis in S. version 2.39-5, https://CRAN.R-project.org/package=survival.

Uhlmann S.S., Broadhurst M.K. 2015. Mitigating unaccounted fishing mortality from gillnets and traps. Fish Fish. 16: 183-229. https://doi.org/10.1111/faf.12049

Yang T.-H, Lai N.C., Graham J.B., et al. 1992. Respiratory, blood and heart enzymatic adaptations of Sebastolobus alascanus (Scorpaenidae; Teleostei) to the oxygen minimum zone: a comparative study. Biol. Bull. 183: 490-499. https://doi.org/10.2307/1542026 